\title{
Pseudonocardia carboxydivorans sp. nov., a carbon monoxide-oxidizing actinomycete, and an emended description of the genus Pseudonocardia
}

Correspondence

Young M. Kim

young547@yonsei.ac.kr

\author{
Sae W. Park, Sang T. Park, † Jung E. Lee and Young M. Kim \\ Molecular Microbiology Laboratory, Department of Biology, Yonsei University, Seoul 120-749, \\ Republic of Korea
}

\begin{abstract}
A bacterial strain, $\mathrm{Y}^{\top}{ }^{\top}$, capable of oxidizing carbon monoxide, was isolated from a soil sample collected from a roadside in Seoul, Korea. On the basis of 16S rRNA gene sequence similarity analyses, strain $Y 8^{\top}$ was shown to belong to the genus Pseudonocardia and was related most closely to the type strain of Pseudonocardia alni (99.6\% similarity). The cells were aerobic and stained Gram-positive, with white aerial mycelium and brown substrate mycelium. The predominant fatty acids were $16: 0$ iso and $16: 1$ iso. The cell-wall peptidoglycan of strain $\mathrm{Y}^{\top}$ contained meso-diaminopimelic acid. The DNA G+C content was 77 mol\%. Strain $Y^{\top}$ contained MK-9 as the major menaquinone, which is different from the major menaquinone reported previously in the genus $P$ seudonocardia, MK-8 $\left(\mathrm{H}_{4}\right)$. DNA-DNA relatedness between strain $\mathrm{Y}^{\top}$ and the type strains of $P$. alni and Pseudonocardia antarctica was respectively 10 and $63 \%$. Based on phylogenetic, morphological and chemotaxonomic evidence, it is proposed that strain $\mathrm{Y}^{\top}\left(=\mathrm{KCCM} 42678^{\top}=\mathrm{JCM} 14827^{\top}\right)$ be classified as the type strain of a novel species, Pseudonocardia carboxydivorans sp. nov. An emended description of the genus Pseudonocardia is also presented.
\end{abstract}

The genus Pseudonocardia was first established by Henssen (1957). The genus presently comprises 27 species and has the following characteristics: vegetative and aerial mycelia with spore chains produced by acropetal budding or fragmentation, meso-diaminopimelic acid, arabinose and galactose in the peptidoglycan (type IV cell-wall composition), MK- $8\left(\mathrm{H}_{4}\right)$ as the major menaquinone, iso-branched hexadecanoic acid as the predominant fatty acid, phospholipid type PII (phosphatidylethanolamine or its derivatives as a diagnostic phospholipid) or PIII (phosphatidylcholine) pattern, depending on the species, and a DNA $\mathrm{G}+\mathrm{C}$ content of $68-79 \mathrm{~mol} \%$ (Lee et al., 2001; Huang et al., 2002).

Carbon monoxide (CO) is produced in large quantities by the incomplete combustion of carbonaceous materials used as fuels and is the most abundant and widely distributed air pollutant found in the lower atmosphere (Samoli et al.,

tPresent address: Division of Infectious Diseases, Children's Hospital Boston, Harvard Medical School, Boston, MA 02115, USA.

The GenBank/EMBL/DDBJ accession number for the 16S rRNA gene sequence of strain $\mathrm{Y}^{\top}{ }^{\top}$ is EF114314.

A list of CO-utilizing bacteria, an HPLC trace of the menaquinones of strain $Y 8^{\top}$, a scanning electron micrograph of aerial mycelium of strain $Y 8^{\top}$ and a comparison of its fatty acid profile with those of related strains are available as supplementary material with the online version of this paper.
2007; Sohn et al., 1999). CO occurs in non-urban and urban atmospheres at about 45-250 p.p.b. (Novelli et al., 1994) and 2.2-4.5 p.p.m. (Holmes et al., 2005), respectively. CO is oxidized by micro-organisms living in soil and water, for example carboxydobacteria (Ferry, 1995; Kim \& Hegeman, 1983; Meyer \& Schlegel, 1983), homoacetogenic bacteria (Conrad, 1996; Ferry, 1995), phototrophic bacteria (Conrad, 1996; Ferry, 1995), methanotrophic bacteria (Bedard \& Knowles, 1989) and methanogenic bacteria (Zeikus et al., 1985) (see Supplementary Table S1, available in IJSEM Online), as well as algae (Chappelle, 1962) and fungi (Inman \& Ingersoll, 1971).

Carboxydobacteria are a group of aerobic bacteria that can grow aerobically on $\mathrm{CO}$ as the sole source of carbon and energy (Kim \& Hegeman, 1983; Meyer \& Schlegel, 1983). Our previous studies have focused on carboxydobacteria able to grow at high CO concentrations (300 000 p.p.m.), but, in this study, we have isolated and characterized a novel carboxydobacterium able to grow at a low CO concentration (400 p.p.m.).

Strain $\mathrm{Y}^{\mathrm{T}}$ was isolated from soil collected from a roadside in Seoul, Korea. For the enrichment of aerobic bacteria growing on a low concentration of $\mathrm{CO}$, a primary enrichment was established using $20 \mathrm{~g}$ (fresh weight) samples of soil that were transferred into $500 \mathrm{ml}$ flasks and incubated under 400 p.p.m. CO in air for 2 weeks at $30{ }^{\circ} \mathrm{C}$. Secondary enrichment was initiated by transferring 
$2 \mathrm{~g}$ of the primary enrichment to a $500 \mathrm{ml}$ flask containing $200 \mathrm{ml}$ liquid mineral medium (Kim \& Hegeman, 1981) supplemented with 400 p.p.m. CO in air and $0.005 \%$ (w/ v) yeast extract. The flask was incubated for 2 weeks at $30{ }^{\circ} \mathrm{C}$ with shaking at 200 r.p.m. Portions $(1 \mathrm{ml})$ of the enrichments were then spread on solid mineral medium supplemented with $0.2 \%(\mathrm{w} / \mathrm{v})$ glucose and incubated for 2 weeks at $30{ }^{\circ} \mathrm{C}$ under 400 p.p.m. CO in air (Hardy \& King, 2001). Strain $\mathrm{Y}^{\mathrm{T}}$ grew slowly on mineral medium supplemented with $0.2 \%(\mathrm{w} / \mathrm{v})$ glucose at $30{ }^{\circ} \mathrm{C}$ under 400 p.p.m. $\mathrm{CO}$ in air, but did not grow under a high $\mathrm{CO}$ concentration (300000 p.p.m.). The CO dehydrogenase (CO-DH) enzyme assay was carried out according to Kraut et al. (1989) and revealed that strain $\mathrm{Y}^{\mathrm{T}}$ was able to oxidize CO [1.2 nmol 2-(4-indophenyl)-3-(4-nitrophenyl)$2 \mathrm{H}$-tetrazolium chloride $\left(\varepsilon_{496}=17.981 \mathrm{mM}^{-1} \mathrm{~cm}^{-1}\right)$ reduced per $\mathrm{mg}$ protein per minute].

The morphological characteristics of strain $\mathrm{Y}^{\mathrm{T}}$ were observed by scanning electron microscopy of a 14-dayold culture grown on Bennett's medium. An LEO 1455VP scanning electron microscope was used. Members of the genus Pseudonocardia are characterized morphologically by the formation of well-developed vegetative and aerial mycelium, from which spore chains are produced by acropetal budding or fragmentation (Lee et al., 2001; Huang et al., 2002). Strain $\mathrm{Y}^{\mathrm{T}}$ showed morphology typical of the genus Pseudonocardia. Strain $\mathrm{Y}^{\mathrm{T}}$ formed brown substrate and white aerial mycelia. The aerial mycelium fragmented into rod-shaped spores. The spore surface was smooth (Supplementary Fig. S1). Gram-staining and physiological tests were carried out by following the procedures of Gerhardt et al. (1994) and Gordon et al. (1974), respectively. Carbon utilization of a variety of substrates was examined by MicroID (Daejeon, Korea) using a Biolog GP2 MicroPlate. Strain $\mathrm{Y}^{\mathrm{T}}$ was aerobic and stained Gram-positive. Detailed physiological properties of strain $\mathrm{Y}^{\mathrm{T}}$ are provided in the species description. Some characteristic and differential properties from phylogenetically closely related Pseudonocardia species are shown in Table 1.

Total genomic DNA from strain $\mathrm{Y}^{\mathrm{T}}$ was isolated by using cetyltrimethylammonium bromide (Ausubel et al., 1995). PCR amplification of the 16S rRNA gene using universal primers 27F (5'-AGAGTTTGATCMTGGCTCAG-3') and 1525R (5'-AAGGAGGTGWTCCARCC-3') was carried out as described by Lane (1991). Amplified DNA fragments were purified from agarose gels using a gel extraction kit (iNtRON) and sequenced. Phylogenetic analysis was performed by using MEGA version 3.1 (Kumar et al., 2004) after multiple alignment of data by CLUSTAL_X (Thompson et al., 1997). 16S rRNA gene sequence studies indicated that strain $\mathrm{Y}^{\mathrm{T}}{ }^{\mathrm{T}}$ is related to members of the genus Pseudonocardia (Fig. 1). The nearly complete $16 \mathrm{~S}$ rRNA gene sequence of strain $\mathrm{Y}^{\mathrm{T}}$ was a continuous stretch of 1322 bp. Sequence similarity calculations after neighbourjoining analysis indicated that the closest relatives of strain $\mathrm{Y}^{\mathrm{T}}$ are Pseudonocardia alni IMSNU $20049^{\mathrm{T}} \quad(99.6 \%$
Table 1. Phenotypic differences between strain $Y 8^{\top}$ and type strains of closely related species of the genus Pseudonocardia

Strains: 1, strain $\mathrm{Y}^{\mathrm{T}} ; 2$, P. alni DSM $44104^{\mathrm{T}}$ (data from Prabahar et al., 2004); 3, P. antarctica DSM $44749^{\mathrm{T}}$ (Prabahar et al., 2004); 4, P. autotrophica IMSNU $20050^{\mathrm{T}}$ (Lee et al., 2001); 5, P. compacta IMSNU $20111^{\mathrm{T}}$ (Lee et al., 2001). +, Positive or present; (+), weakly positive; - , negative or absent; ND, no data available. All strains were negative for hydrolysis of casein and did not grow at $4{ }^{\circ} \mathrm{C}$.

\begin{tabular}{|c|c|c|c|c|c|}
\hline Test & 1 & 2 & 3 & 4 & 5 \\
\hline \multicolumn{6}{|c|}{ Acid produced from: } \\
\hline Cellobiose & - & - & - & + & + \\
\hline D-Fructose & - & + & - & + & + \\
\hline D-Galactose & - & - & + & + & - \\
\hline myo-Inositol & - & - & - & + & - \\
\hline Inulin & + & - & + & $\mathrm{ND}$ & ND \\
\hline Maltose & - & - & + & + & - \\
\hline D-Mannitol & - & - & $(+)$ & + & + \\
\hline D-Mannose & - & - & + & $\mathrm{ND}$ & - \\
\hline Melezitose & - & - & - & + & - \\
\hline L-Rhamnose & - & $(+)$ & + & - & - \\
\hline D-Ribose & - & - & + & ND & ND \\
\hline Sorbitol & - & + & - & + & - \\
\hline Sucrose & - & + & - & + & - \\
\hline Trehalose & - & + & - & + & - \\
\hline D-Xylose & - & - & + & + & - \\
\hline \multicolumn{6}{|l|}{ Hydrolysis of: } \\
\hline Gelatin & - & + & + & - & - \\
\hline Starch & - & + & + & - & - \\
\hline Urease activity & + & + & + & + & - \\
\hline \multicolumn{6}{|l|}{ Growth at/on: } \\
\hline $37{ }^{\circ} \mathrm{C}$ & + & + & + & + & - \\
\hline $3 \% \mathrm{NaCl}$ & + & + & + & + & - \\
\hline $4 \% \mathrm{NaCl}$ & + & + & + & + & - \\
\hline $5 \% \mathrm{NaCl}$ & - & + & + & + & - \\
\hline
\end{tabular}

similarity) and Pseudonocardia antarctica DVS $5 \mathrm{a} 1^{\mathrm{T}}$ (99.5\%) (Fig. 1).

Whole-cell fatty acid methyl ester analysis and menaquinone composition analysis were performed according to Sasser (1990) and Wu et al. (1989), respectively, by the Korean Culture Center of Micro-organisms (KCCM, Seoul, Korea). The diaminopimelic acid composition of strain $\mathrm{Y}^{\mathrm{T}}$ was determined according to Staneck \& Roberts (1974) by MicroID. The most abundant fatty acids found in $\mathrm{Y}^{\mathrm{T}}$ were $16: 0$ iso $(47.2 \%)$ and $16: 1$ iso $(22.8 \%)$. Analysis of the fatty acid profile also revealed the presence of smaller amounts of 15:0 iso (5.0\%), 16:1 cis9 (5.9\%), 16:0 10methyl (4.6\%), $17: 0$ iso (3.0\%), $17: 0$ anteiso $(2.6 \%)$ and $17: 1$ cis $9(2.4 \%)$. The fatty acid 16:0 iso is also found in the highest concentrations in $P$. alni, $P$. antarctica, $P$. asaccharolytica, $P$. autotrophica, $P$. compacta, P. halophobica, $P$. hydrocarbonoxydans, $P$. kongjuensis and $P$. sulfidoxydans (Lee et al., 2001; Prabahar et al., 2004; Reichert et al., 1998) (Supplementary Table S2). The major menaquinone of strain $\mathrm{Y}^{\mathrm{T}}$ was MK-9 (Supplementary Fig. S2), which is 


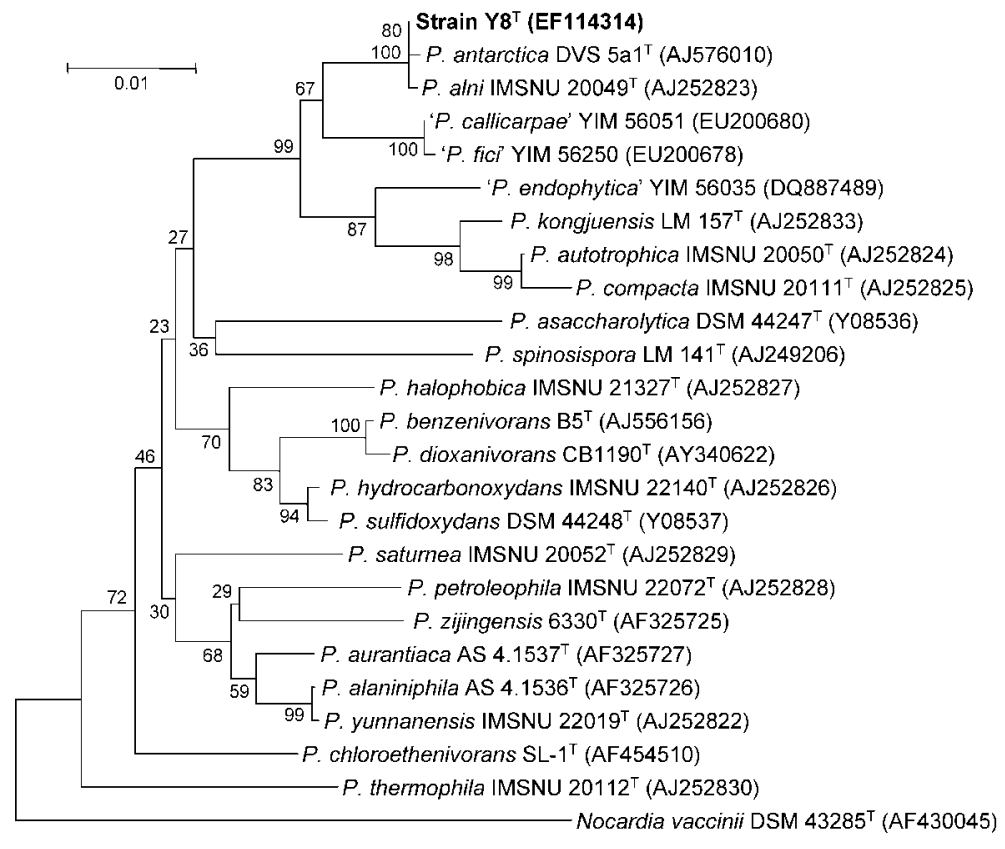

Fig. 1. Phylogenetic tree based on $16 \mathrm{~S}$ rRNA gene sequences showing the position of strain $\mathrm{Y}^{\top}{ }^{\top}$ in the genus Pseudonocardia. The tree was constructed by the neighbour-joining method (Saitou \& Nei, 1987) based on a comparison of 1322 unambiguous nucleotide positions. Numbers at branching points are percentages of occurrence in 1000 bootstrapped trees. Bar, 1 substitution per 100 nucleotide positions. different from the major menaquinone reported for the genus Pseudonocardia, MK-8 $\left(\mathrm{H}_{4}\right)$ (Embley et al., 1988; Huang et al., 2002). Strain $\mathrm{Y}^{\mathrm{T}}$ contained meso-diaminopimelic acid as a cell-wall diamino acid.

DNA-DNA hybridization experiments were performed between strain $\mathrm{Y}^{\mathrm{T}}$ and the type strains of $P$. alni and $P$. antarctica, using the method described by Nicholas et al. (2002). DNA-DNA hybridization showed that strain $\mathrm{Y}^{\mathrm{T}}$ exhibited low levels of DNA relatedness to its phylogenetic neighbours $P$. alni DSM $44104^{\mathrm{T}}(10 \pm 0.6 \%$, mean \pm SD of three hybridizations) and $P$. antarctica DSM $44749^{\mathrm{T}}$ ( $63 \pm 7.0 \%$, mean \pm SD of five hybridizations). The DNA base composition was determined according to Mesbah et al. (1989) by the KCCM. The $\mathrm{G}+\mathrm{C}$ content of strain $\mathrm{Y}^{\mathrm{T}}$ was $77 \mathrm{~mol} \%$.

The observation that strain $\mathrm{Y}^{\mathrm{T}}$ contains $\mathrm{MK}-9$ as the major menaquinone necessitates a further emendation of the description of the genus Pseudonocardia.

\section{Description of Pseudonocardia carboxydivorans sp. nov.}

Pseudonocardia carboxydivorans (car.bo.xy'di.vo' rans. N.L. neut. n. carboxydum carbon monoxide; L. part. adj. vorans devouring, digesting; N.L. part. adj. carboxydivorans digesting carbon monoxide).

Aerobic, Gram-positive, non-motile actinomycete. Forms brown substrate mycelium and white aerial mycelium. The aerial mycelium fragments into rod-shaped spores. Grows optimally at $25{ }^{\circ} \mathrm{C}$ and tolerates up to $4 \%($ w/v) $\mathrm{NaCl}$. Positive for catalase and urease, but negative for oxidase. Utilizes $N$-acetyl-D-glucosamine, inulin and mannan but not cellobiose, D-fructose, D-galactose, myo-inositol, maltose, D-mannitol, D-mannose, melezitose, raffinose,
L-rhamnose, D-ribose, sorbitol, sucrose, trehalose, xylitol or D-xylose as sole carbon sources. meso-Diaminopimelic acid is present in the cell wall and MK-9 is the major menaquinone. Predominant fatty acids are 16:0 iso and $16: 1$ iso. The $\mathrm{G}+\mathrm{C}$ content of the type strain is $77 \mathrm{~mol} \%$. The type strain, $\mathrm{Y}^{\mathrm{T}}\left(=\mathrm{KCCM} 42678^{\mathrm{T}}=\mathrm{JCM} 14827^{\mathrm{T}}\right)$, was isolated from soil collected at a roadside in Seoul, Korea.

\section{Emended description of the genus Pseudonocardia Henssen 1957 emend. Huang et al. 2002}

The description of the genus is as emended by Huang et al. (2002), with the exception that the major menaquinone is MK-8 $\left(\mathrm{H}_{4}\right)$ or MK-9 $\left(\mathrm{H}_{0}\right)$.

\section{Acknowledgements}

This work was supported by a research grant (F01-2003-000-0004-0) from the Korea Science and Engineering Foundation.

\section{References}

Ausubel, F. M., Brent, R., Kingston, R. E., Moore, D. D., Seidman, J. G., Smith, J. A. \& Struhl, K. (1995). Current Protocols in Molecular Biology. New York: Wiley.

Bedard, C. \& Knowles, R. (1989). Physiology, biochemistry, and specific inhibitors of $\mathrm{CH}_{4}, \mathrm{NH}_{4}$, and $\mathrm{CO}$ oxidation by methanotrophs and nitrifiers. Microbiol Rev 53, 68-84.

Chappelle, E. W. (1962). Carbon monoxide oxidation by algae. Biochim Biophys Acta 62, 45-62.

Conrad, R. (1996). Soil microorganisms as controllers of atmospheric trace gases $\left(\mathrm{H}_{2}, \mathrm{CO}, \mathrm{CH}_{4}, \mathrm{OCS}, \mathrm{N}_{2} \mathrm{O}\right.$, and $\left.\mathrm{NO}\right)$. Microbiol Rev 60, 609-640. 
Embley, T. M., Smida, J. \& Stackebrandt, E. (1988). The phylogeny of mycolate-less wall chemotype IV actinomycetes and the description of Pseudonocardiaceae fam. nov. Syst Appl Microbiol 11, 44-52.

Ferry, J. G. (1995). CO dehydrogenase. Annu Rev Microbiol 49, 305333.

Gerhardt, P., Murray, R. G. E., Wood, W. A. \& Krieg, N. R. (editors) (1994). Methods for General and Molecular Bacteriology. Washington, DC: American Society for Microbiology.

Gordon, R. E., Barnett, D. A., Handerhan, J. E. \& Pang, C. H.-N. (1974). Nocardia coeliaca, Nocardia autotrophica, and the nocardin strain. Int J Syst Bacteriol 24, 54-63.

Hardy, K. R. \& King, G. M. (2001). Enrichment of high-affinity CO oxidizers in Maine forest soil. Appl Environ Microbiol 67, 3671-3676.

Henssen, A. (1957). Beiträge zur Morphologie und Systematik der thermophilen Actinomyceten. Arch Mikrobiol 26, 373-414 (in German).

Holmes, N. S., Morawska, L., Mengersen, K. \& Jayaratne, E. R. (2005). Spatial distribution of submicrometre particles and CO in an urban microscale environment. Atmos Environ 39, 3977-3988.

Huang, Y., Wang, L., Lu, Z., Hong, L., Liu, Z., Tan, G. Y. A. \& Goodfellow, M. (2002). Proposal to combine the genera Actinobispora and Pseudonocardia in an emended genus Pseudonocardia, and description of Pseudonocardia zijingensis sp. nov. Int J Syst Evol Microbiol 52, 977-982.

Inman, R. E. \& Ingersoll, R. B. (1971). Uptake of carbon monoxide by soil fungi. J Air Pollut Control Assoc 21, 646-647.

Kim, Y. M. \& Hegeman, G. D. (1981). Purification and some properties of carbon monoxide dehydrogenase from Pseudomonas carboxydohydrogena. J Bacteriol 148, 904-911.

Kim, Y. M. \& Hegeman, G. D. (1983). Oxidation of carbon monoxide by bacteria. Int Rev Cytol 81, 1-32.

Kraut, M., Hugendieck, l., Herwig, S. \& Meyer, O. (1989). Homology and distribution of $\mathrm{CO}$ dehydrogenase structural genes in carboxydotrophic bacteria. Arch Microbiol 152, 335-341.

Kumar, S., Tamura, K. \& Nei, M. (2004). MEGA3: integrated software for molecular evolutionary genetics analysis and sequence alignment. Brief Bioinform 5, 150-163.

Lane, D. J. (1991). 16S/23S rRNA sequencing. In Nucleic Acid Techniques in Bacterial Systematics, pp. 115-175. Edited by E. Stackebrandt \& M. Goodfellow. Chichester: Wiley.

Lee, S. D., Kim, E. S., Min, K.-L., Lee, W. Y., Kang, S.-O. \& Hah, Y. C. (2001). Pseudonocardia kongjuensis sp. nov., isolated from a gold mine cave. Int J Syst Evol Microbiol 51, 1505-1510.
Mesbah, M., Premachandran, U. \& Whitman, W. B. (1989). Precise measurement of the $\mathrm{G}+\mathrm{C}$ content of deoxyribonucleic acid by highperformance liquid chromatography. Int J Syst Bacteriol 39, 159-167.

Meyer, O. \& Schlegel, H. G. (1983). Biology of aerobic carbon monoxide oxidizing bacteria. Annu Rev Microbiol 37, 277-310.

Nicholas, R. A., Khan, L. A., Houshaymi, B., Miles, R. J., Ayling, R. D., Hotzel, H. \& Sachse, K. (2002). Close genetic and phenotypic relatedness between Mycoplasma ovine/caprine serogroup 11 and Mycoplasma bovigenitalium. Syst Appl Microbiol 25, 396-402.

Novelli, P. C., Masarie, K. A., Tans, P. P. \& Lang, P. M. (1994). Recent changes in atmospheric carbon monoxide. Science 263, 1587-1590.

Prabahar, V., Dube, S., Reddy, G. S. N. \& Shivaji, S. (2004). Pseudonocardia antarctica sp. nov. an Actinomycetes from McMurdo Dry Valleys, Antarctica. Syst Appl Microbiol 27, 66-71.

Reichert, K., Lipski, A., Pradella, S., Stackebrandt, E. \& Altendorf, K. (1998). Pseudonocardia asaccharolytica sp. nov. and Pseudonocardia sulfidoxydans sp. nov., two new dimethyl disulfide-degrading actinomycetes and emended description of the genus Pseudonocardia. Int J Syst Bacteriol 48, 441-449.

Saitou, N. \& Nei, M. (1987). The neighbor-joining method: a new method for reconstructing phylogenetic trees. Mol Biol Evol 4, 406-425.

Samoli, E., Touloumi, G., Schwartz, J., Anderson, H. R., Schindler, C., Forsberg, B., Vigotti, M. A., Vonk, J., Kosnik, M. \& other authors (2007). Short-term effects of carbon monoxide on mortality: an analysis within the APHEA project. Environ Health Perspect 115, 1578-1583.

Sasser, M. (1990). Identification of bacteria through fatty acid analysis. In Methods in Phytobacteriology, pp. 199-204. Edited by Z. Klement, K. Rudolph \& D. C. Sands. Budapest: Akademiai Kiado.

Sohn, S. H., Oh, S. C. \& Yeo, Y.-K. (1999). Prediction of air pollutants by using an artificial neural network. Korean J Chem Eng 16, 382-387.

Staneck, J. L. \& Roberts, G. D. (1974). Simplified approach to the identification of aerobic actinomycetes by thin-layer chromatography. Appl Microbiol 28, 226-231.

Thompson, J. D., Gibson, T. J., Plewniak, F., Jeanmougin, F. \& Higgins, D. G. (1997). The CLUSTAL_X windows interface: flexible strategies for multiple sequence alignment aided by quality analysis tools. Nucleic Acids Res 25, 4876-4882.

Wu, C., Lu, X., Qin, M., Wang, Y. \& Ruan, J. (1989). Analysis of menaquinone compound in microbial cells by HPLC. Microbiology [English translation of Microbiology (Beijing)] 16, 176-178.

Zeikus, J. G., Kerby, R. \& Krzycki, J. A. (1985). Single-carbon chemistry of acetogenic and methanogenic bacteria. Science 227, 1167-1173. 